\title{
Research on Technological Standard Innovation of Liaoning Equipment Manufacturing Industrial Cluster
}

\author{
Le Wang ${ }^{\mathrm{a}^{*}}$, Xuan $\mathrm{Wu}^{\mathrm{b}}$ and Qingman $\mathrm{Li}^{\mathrm{c}}$ \\ Bohai University, Jinzhou, Liaoning, China \\ alewang1982@163.com, b2224175207@qq.com, ${ }^{9}$ lqm5189@163.com
}

\begin{abstract}
Keywords: Technological standard innovation; Equipment manufacturing industry; Industrial cluster; Made in China 2025; Liaoning province
\end{abstract}

\begin{abstract}
Equipment manufacturing industry is the pillar and basic industry of economic and social development. Liaoning provincial government gives priority to the development of advanced equipment manufacturing industry in the "Made in China 2025 Liaoning action outline". At present, Liaoning has strong competitiveness of the manufacturing industry in the field of intelligent manufacturing equipment, electric power equipment, new energy equipment, rail transit equipment, aerospace equipment, ship and marine equipment, petrochemical equipment, metallurgical complete sets of equipment, and agricultural equipment. Technical standard innovation can promote the overall innovation of equipment manufacturing industrial cluster, and the innovation of technical standards determines the development direction of manufacturing technology innovation. So it's very necessary to use technological standard innovation to promote the transformation and upgrading of equipment manufacturing industry, Liaoning province should enhance the standardization innovation ability, implement basic industrial standards, develop intelligent manufacturing standards, develop green manufacturing standards, and strengthen the training of standardized talents.
\end{abstract}

\section{Introduction}

In May 2015, China's State Council issued the "Made in China 2025" strategy, focus on supporting the new generation information technology, high grade $\mathrm{CNC}$ machine tools and robots, aerospace equipment, marine engineering equipment and high technology ships, advanced rail transportation equipment, energy-saving and new energy vehicles, electric power equipment, new materials, bio medicine and high performance medical equipment, agricultural machinery and equipment, China want to seek innovation-driven development, apply smart technologies, strengthen foundations, pursue green development, and redouble efforts to upgrade China from a manufacturer of quantity to one of quality.[1-5]

In December 2015, Liaoning provincial government issued the "Made in China 2025 Liaoning action outline" to enhance the core competitiveness and sustainable development capacity of the industry. In traditional manufacturing industry, promote the transformation of traditional industries from factor driven to innovation driven, give priority to the development of advanced equipment manufacturing industry, promote key areas of high-end equipment and complete sets of major equipment to accelerate development, promote the integration of the new generation of information technology and equipment manufacturing industry, the construction of the national high-end equipment, intelligent equipment manufacturing industry base and strategic core zone. In strategic emerging industries, give priority to the development of new generation information technology, high grade CNC machine tools, robotics, biomedical, energy saving and environmental protection, new energy, new materials, new energy vehicles and aircraft, support the development of software and information technology services, integrated circuits, energy storage, marine engineering equipment and other industries. [6]

Equipment manufacturing industry is the pillar and basic industry of economic and social development. [7] Standards are the core elements of industrial development and the basis of quality and technology, and play important roles in the whole process of equipment design, manufacturing, 
procurement, inspection, use and maintenance.[8] The technical level and competitiveness of equipment quality are determined by the progressiveness, coordination and systematicness of the standards. Standardization of equipment manufacturing industry has played an active role in improving product quality, expanding international trade, promoting technological progress and innovation in Liaoning Province. However, with the integration of new generation of information technology and equipment manufacturing, there is a lack of standards for intelligent manufacturing and green manufacturing in the standard system of Liaoning equipment manufacturing industry, and standard internationalization is very low.[9] Therefore, it's very necessary to use technological standard innovation to promote the transformation and upgrading of equipment manufacturing industry.

\section{The Development of Liaoning Equipment Manufacturing Industrial Cluster}

Liaoning is the most powerful province of equipment manufacturing in Northeast China which has strong competitiveness of the manufacturing industry in the field of CNC machine tools, large ships, mining machinery, power transmission equipment, railway locomotives and other equipment. The key support manufacturing industries and major production bases of Liaoning province is shown in Table 1.

In 2015, Liaoning province has 5010 equipment manufacturing enterprises above designated size, total assets is 1.16 trillion yuan, main business income is 1.18 trillion yuan, and get a profit of 57.6 billion yuan. The equipment manufacturing industry output value accounted for about $1 / 3$ of the total industrial output value of Liaoning. ${ }^{[10]}$

\section{The Impact of Technological Innovation on Equipment Manufacturing Industry}

Technical standard innovation can promote the overall innovation of equipment manufacturing industrial cluster. Industrial cluster is a regional network system by distribution in a specific geographic space range, due to division of labor relations and a group of enterprise aggregation formation. Industrial cluster has become a common social and economic phenomenon at home and abroad, and it is also a strategic task for the development of local governments at all levels. The establishment and innovation cooperation technology standard has a wide range of participants, key manufacturers, suppliers, producers and users of complementary products, service providers, universities, research institutions, associations and relevant government organizations in different ways to the process effect. Obviously, the innovation of technical standards and the formation and development of industrial clusters have similar network basis. The innovation of technical standards can promote the innovation of industrial clusters, and then realize the optimization and upgrading of industrial clusters.

The innovation of technical standards determines the development direction of manufacturing technology innovation. In a certain period of time, there may be several technologies. Different companies develop along their respective technological trajectories, and competing with each other. Once a technology wins and becomes a technical standard, in order to reduce the market uncertainty, relevant manufacturers and consumers will operate according to this standard, and continue to promote the development of related technologies along the track of the technology. Generally speaking, those standards with more users and more accessory products will guide the technology development direction. The raw material cost and production cost of equipment manufacturing enterprises are very high, so these enterprises should choose the right standards to be the foundation of future development.

Technical standards determine the equipment manufacturing industry position in the international industrial chain. The enterprises in developed countries have core technologies in some key areas, and have the right to develop international standards, including statutory and factual standards, then control the key link of the international industrial chain, and get more monopoly profits. On the other hand, Because of the lack of core technology, the equipment manufacturing industry in developing 
countries is in the passive position; manufacturing enterprises have to implement standards from developed countries. So, if the equipment manufacturing enterprises want to get rid of the status quo, it must be transformed from the implementation of standards to create standards. This can also make the "made in Liaoning" change to "Liaoning create".

Table 1 Key support manufacturing industries and major production bases of Liaoning province

\begin{tabular}{|c|c|c|}
\hline $\begin{array}{l}\text { Key support } \\
\text { Clusters }\end{array}$ & Main products & Major production bases \\
\hline $\begin{array}{l}\text { Intelligent } \\
\text { manufacturing } \\
\text { equipment }\end{array}$ & $\begin{array}{l}\text { High precision and high performance } \\
\text { precision measuring equipment, } \\
\text { high-precision numerical control } \\
\text { equipment, 3D printing equipment, } \\
\text { robots }\end{array}$ & $\begin{array}{l}\text { Shenyang intelligent equipment industry } \\
\text { base; Shenyang robot industrial base; } \\
\text { Dalian intelligent manufacturing } \\
\text { equipment base; Fushun intelligent } \\
\text { equipment base; Anshan laser electronic } \\
\text { and automation equipment industry base }\end{array}$ \\
\hline $\begin{array}{l}\text { Electric power } \\
\text { equipment }\end{array}$ & $\begin{array}{l}\text { Large ultra clean coal power unit, } \\
\text { nuclear power equipment, super large } \\
\text { capacity hydroelectric generating set, } \\
\text { heavy duty gas turbine, ehv power } \\
\text { transmission equipment,smart grid } \\
\text { equipment }\end{array}$ & $\begin{array}{l}\text { Shenyang electric power equipment } \\
\text { manufacturing base; } \\
\text { Dalian battery energy storage equipment } \\
\text { industrialization base }\end{array}$ \\
\hline $\begin{array}{l}\text { New energy } \\
\text { equipment }\end{array}$ & $\begin{array}{l}\text { High power wind turbine, high } \\
\text { conversion solar cell module, grid } \\
\text { connected power station }\end{array}$ & $\begin{array}{l}\text { Dalian wind power core components } \\
\text { development base; Chaoyang new energy } \\
\text { industry base; Jinzhou photovoltaic } \\
\text { industry base }\end{array}$ \\
\hline $\begin{array}{l}\text { Rail transit } \\
\text { equipment }\end{array}$ & $\begin{array}{l}\text { High speed EMU, new type diesel } \\
\text { locomotive, railway freight car, modern } \\
\text { tram, urban rail transit control system, } \\
\text { locomotive microcomputer control } \\
\text { system, locomotive signal equipment }\end{array}$ & $\begin{array}{l}\text { Dalian rail transit equipment manufacturing } \\
\text { base; Liaoyang equipment manufacturing } \\
\text { industry base }\end{array}$ \\
\hline $\begin{array}{l}\text { Aerospace } \\
\text { equipment }\end{array}$ & $\begin{array}{l}\text { Helicopters, general purpose aircraft, } \\
\text { light multi-purpose aircraft, regional } \\
\text { aircraft, unmanned aerial vehicles } \\
\text { (UAV), satellites, spacecraft, new aero } \\
\text { engines, aircraft transmission systems }\end{array}$ & $\begin{array}{l}\text { Shenyang aviation equipment } \\
\text { manufacturing base; Dalian general } \\
\text { aviation industry base }\end{array}$ \\
\hline $\begin{array}{l}\text { Ship and } \\
\text { marine } \\
\text { equipment }\end{array}$ & $\begin{array}{l}\text { High technology ships, large ocean going } \\
\text { ships, luxury cruise ships, marine } \\
\text { mineral resources development } \\
\text { equipment, deep sea exploration } \\
\text { equipment, marine operation equipment }\end{array}$ & $\begin{array}{l}\text { Dalian ship and marine equipment base; } \\
\text { Huludao marine equipment manufacturing } \\
\text { base; Panjin- Yingkou marine equipment } \\
\text { manufacturing base }\end{array}$ \\
\hline $\begin{array}{l}\text { Table } 1 \text { cont. } \\
\text { Petrochemical } \\
\text { equipment }\end{array}$ & $\begin{array}{l}\text { Large petrochemical products complete } \\
\text { sets of production lines, large liquefied } \\
\text { natural gas production lines, large-scale } \\
\text { coal chemical production line, large } \\
\text { high-quality oil refining equipment, oil } \\
\text { drilling equipment }\end{array}$ & $\begin{array}{l}\text { Shenyang petrochemical equipment base; } \\
\text { Dalian Petrochemical General equipment } \\
\text { base; Panjin oil and gas equipment base }\end{array}$ \\
\hline $\begin{array}{l}\text { Metallurgical } \\
\text { complete sets of } \\
\text { equipment }\end{array}$ & $\begin{array}{l}\text { Large efficient metal cold hot rolling } \\
\text { mill, high efficiency finishing equipment } \\
\text { for iron and steel, high iron ore roasting } \\
\text { equipment, high end hydraulic } \\
\text { equipment }\end{array}$ & $\begin{array}{l}\text { Fuxin hydraulic industrial base; Dalian } \\
\text { metallurgical equipment manufacturing } \\
\text { base; Liaoyang aluminum processing } \\
\text { industry base }\end{array}$ \\
\hline $\begin{array}{l}\text { Agricultural } \\
\text { equipment }\end{array}$ & $\begin{array}{l}\text { Combine harvester, precision seeding } \\
\text { and fertilizing soil preparation } \\
\text { machinery, advanced machinery, animal } \\
\text { husbandry machinery, agricultural } \\
\text { machinery control system }\end{array}$ & $\begin{array}{l}\text { Shenyang agricultural machinery } \\
\text { equipment manufacturing base }\end{array}$ \\
\hline
\end{tabular}




\section{Technological Standard Innovation of Liaoning Equipment Manufacturing Industrial Cluster}

Enhance the Standardization Innovation Ability. Increase scientific and technological research and development support for the development of standards, add the quality and stability of the research and development products, equipment availability and product life expectancy in the project design, project implementation and project acceptance. Study on the key technical standards of equipment manufacturing industry on the basis of national quality common technology research and application. Improve the basic public service system of industrial technology and strengthen Industry-University-Institute collaboration around the industrial innovation alliance. Encourage enterprises to transform the results of innovation into technical standards and promote industrialization. Encourage enterprises to develop enterprise standards better than national standards, industry standards, improve the enterprise standard system. Encourage enterprises to participate in the revision of industry standards, national standards and international standards, and undertake the work of the international standardization organization. Encourage consumers, news media and social organizations to supervise the implementation of the product and service standards.

Implement Basic Industrial Standards. Accelerate the formulation of standards on key components, advanced basic technology, critical base material and industry technology foundation. Develop new standards for key components of CNC machine tools, electronic equipment, aerospace equipment, marine engineering equipment, advanced rail transportation equipment, energy-saving and new energy vehicles and other high-end equipment manufacturing industry. Modify the standards of steel, nonferrous metals, electronic special materials, organic and composite materials, hydraulic parts, fasteners, springs and seals. Improve the standards of metal forming, metal processing, heat treatment, forging, casting, welding and surface engineering etc. Technical standards should meet the needs of the market.

Develop Intelligent Manufacturing Standards. Establish coordination mechanism for intelligent manufacturing standardization, Establish collaborative innovation standards to promote the alliance in intelligent products, equipment, manufacturing technology, focus on the development of intelligent manufacturing base of key terms and definitions, intelligent equipment and industrial products, Internet and networking, intelligent and digital factory workshop, industrial software industry, cloud and big data and other general and key technical standards, and norms. Strengthen communication and cooperation with the technical standards of developed countries and regions, actively participate in the international organization for Standardization (ISO), the International Electrotechnical Commission (IEC), the International Telecommunication Union (ITU) and other international organization for standardization activities, make full use of the Sino German intelligent manufacturing industry standardization working group and other cooperation platform, and participate in the formulation of international standards.

Develop Green Manufacturing Standards. Develop the product life cycle standard, Guide equipment manufacturing industry to achieve completely green in the whole life cycle of product design, manufacture, use, recycling and reuse. Study on green production standard of green design, process, equipment, material and management, such as waste heat recovery, water recycling, waste recycling and harmless disposal, and abandoned vehicles and key parts of the system, waste electrical and mechanical products recycling and remanufacturing recycling standards. Implement green procurement, green consumption and green logistics. Achieve the green product standards of lightweight, harmless, energy saving and noise reduction, resource saving, easy disassembly, easy recovery, high reliability and long life. Achieve the green plant standards of land intensive, raw materials harmless, clean production and purification, waste resources, energy and low carbon.

Strengthen the Training of Standardized Talents. Accelerate the development of professional ability, high level of foreign language, familiar with the rules of the international standardization of talent. By carrying out the standardization and quality management of the managers of the equipment manufacturing enterprises, the managers should pay attention to the standardization and quality management. Cultivate workers artisan spirit through standardization propaganda and training, 
Improve the consciousness of workers in accordance with the standards of production and operation. Set up a joint training mechanism of enterprises and universities, and provide more talents for the development of equipment manufacturing industry

\section{Acknowledgements}

This research was supported by the MOE (Ministry of Education in China) Project of Humanities and Social Sciences (Project No. 16YJC630120, "Research on supply chain collaborative innovation mechanism and incentive mechanism of new energy industry cluster: from the perspective of vertical market structure").

\section{References}

[1] S.X. Liu: Design Management Review, Vol.1 (2016) No.27, p.52-58.

[2] S.H. Sun, J.L. Hu, Y. Peng, X.M. Pan: IEEE Wireless Communications, Vol.3 (2016) No.3, p.4-8.

[3] F. Pirajno, T.F. Zhou: Economic Geology, Vol.3(2015) No.110, p.603-629.

[4] M. Reuss, P.J. Marchand, N. Lingbeek: Journal of the Institute of Conservation, Vol.37(2014) No.37, p.120-135.

[5] J.A. Mathews, H. Tan: Carbon Management, Vol.5 (2014) No.1, p.1-3.

[6] Q. Lu, W. Lv, J. Tian, L. Zhang, B. Zhu: Plos One, Vol.10 (2015) No.3, p. e0129121.

[7] L. Guoqing, G. Zeng, J.L. Guo: Scientia Geographica Sinica, Vol.21 (2014) No.1, p.33-50.

[8] G.V.D. Kaa, E.V. Heck, H.J.D. Vries, J.V.D. Ende: IEEE Transactions on Engineering Management, Vol.61 (2014) No.2, p.336-348.

[9] G. Wang, Y. Liu, S. Zhang: China Development, (2014).

[10]XU Lei: Journal of Bohai University, (2014). 